\title{
MULTIPLE SCLEROSIS OUTCOME AND MORBI- MORTALITY OF A BRAZILIAN COHORT PATIENTS
}

\author{
Soniza Vieira Alves-Leon', Fabiola Rachid Malfetano², Maria Lucia Veluttini Pimentel ${ }^{3}$, \\ Claudio Luiz Duque Estrada ${ }^{4}$, Valéria Coelho Santa Rita Pereira ${ }^{4}$, \\ Assuncion Martinez Liem ${ }^{4}$, Sérgio Augusto Pereira Novis ${ }^{5}$
}

\begin{abstract}
We studied the clinical and evolution characteristics of multiple sclerosis (MS) patients followed since the onset of HUCFF/UFRJ in 1978. The diagnosis of MS was based on Poser's et al. and MC Donald's et al. criteria. From 188 patients, 122 were included. Eighty-five were females. The mean age onset was 32.2 yearsold (range 6.0 to $61.0 \pm 10.3$ ), mainly Caucasians ( $82 / 67 \%$ ). The relapsing-remitting course (MSRR) was more frequent (106/86.8\%). Monosymptomatic onset was significantly more frequent in Caucasians than in AfroBrazilians $(p<0.05)$. Seventeen patients had benign form of MS and these patients presented association with MSRR when compared with severe form ( $p=0.01$ ). The mortality rate was $2.12 \%$ ( 4 patients died). This study was similar to other Brazilian series with regard to sex and age, and lack of correlation between EDSS and number of relapses; it confirmed south-southeast African-descendants gradient distribution and association between first mono-symptomatic relapses and Caucasian; we found lower frequency of benign forms.
\end{abstract}

KEY WORDS: multiple sclerosis, mortality, morbidity, epidemiology, Brazil.

\section{Caracteristicas clínico-evolutivas e morbi-mortalidade de uma coorte de pacientes brasileiros com esclerose múltipla}

Resumo - Estudamos as características clínico-evolutivas de pacientes com esclerose múltipla (EM) acompanhados no HUCFF-UFRJ desde 1978. Foram usados critérios de Poser et al. e MC Donald et al. para o diagnóstico de EM. De 188, 122 foram incluídos. Oitenta e cinco eram mulheres. A média de idade de início foi 32,2 anos $(6,0-61,0 \pm 10,3)$, predominando caucasianos $(n=82 / 67 \%)$. A forma recorrente-remitente (EMRR) foi mais freqüente $(n=106 / 86,8 \%)$. Formas mono-sintomáticas no primeiro surto foram significativamente mais freqüentes em caucasianos do que em afro-brasileiros $(p<0,05)$. Dezessete pacientes apresentavam a forma benigna (13,9\%) e 43 a grave (35,2\%). A forma benigna foi associada com a EMRR ( $p=0,01)$. A taxa de letalidade $2,12 \%$ ( 4 óbitos). Nossos resultados são semelhantes aos de outras séries brasileiras no que se refere ao sexo e idade, e falta de correlação entre EDSS e número de surtos; confirmamos gradiente sul-sudeste de distribuição afro-descendente, associação significativa entre primeiro surto mono-sintomático e caucasianos e menor freqüência de formas benignas.

PALAVRAS-CHAVE: esclerose múltipla, mortalidade, morbidade, epidemiologia, Brasil.

Multiple sclerosis (MS) is an inflammatory and neurodegenerative demyelinating disease of central nervous system (CNS) resulting from aberrant immune response to self antigens leading to the destruction of myelin ${ }^{1-7}$.

The natural history of MS shows that the clinical forms ${ }^{8}$ and prognosis may be associated with the age of onset, gender, ethnicity, neurological manifestation of dis- ease onset, frequency of relapses, interval between relapses, interval of time to achieve different levels of disability and immunological profile influenced by several environmental factors?.

This study aims to show the clinical and evolution characteristics of patients with diagnostic criteria for $M^{10,11}$ followed at University Hospital Clementino Fraga

\footnotetext{
'Professora da Disciplina de Neurologia da Universidade Federal do Estado do Rio de Janeiro (UNIRIO), Professora do Programa de Pós-Graduação strictu-senso em Neurologia da UNIRIO e do Programa de Clínica Médica/Neurologia da Universidade Federal do Rio de Janeiro, Rio de Janeiro RJ, Brazil (UFRJ), Docente Livre de Neurologia, Chefe do Setor de Doenças Desmielinizantes do Hospital Universitário Clementino Fraga Filho (HUCFF) da UFRJ; ${ }^{2}$ Neurologista do Hospital Naval Marcílio Dias, Mestre pela UFRJ; ${ }^{3}$ Neurologista, Doutora pela UFRJ; ${ }^{4}$ Mestrando do Programa de Pós-Graduação em Clínica Médica/Neurologia da Faculdade de Medicina da UFRJ; ${ }^{5}$ Professor Titular de Neurologia da Faculdade de Medicina da UFRJ, Chefe do Serviço de Neurologia do HUCFF/UFRJ.
}

Received 11 April 2008, received in final form 16 July 2008. Accepted 25 July 2008.

Dra. Soniza Vieira Alves-Leon - Hospital Universitário Clementino Fraga Filho / Universidade Federal do Rio de Janeiro - Rua Professor Rodolpho Paulo Rocco 255 - 21941-913 Rio de Janeiro RJ - Brasil. E-mail: sonizavleon@globo.com 
Filho (HUCFF-UFRJ) over the last 28 years; verify the different clinical forms ${ }^{8}$ and the variables associated, examine the morbidity and mortality in this group, comparing to Brazilian population studies.

\section{METHOD}

Study bidirectional, in a cohort of patients with MS followed at Hospital Universitário Clementino Fraga Filho (HUCFF) UFRJ, based on the analysis of patients since 1978 - date of its foundation, monitored and discussed by the team of neurologists of the hospital. We included patients diagnosed with MS by criteria of Poser et al. ${ }^{10}$ and McDonald et al. ${ }^{11}$ with clinical forms remitting-relapsing MS (RRMS), secondary progressive MS (SPMS), primary progressive MS (PPMS) and progressive with relapses MS (PRMS) ${ }^{8}$. For neurological disability has been used Kurtzke scale $^{12}$. Expanded Disability Standard Scale (EDSS) values in our sample were measured at two points in the clinical evolution of each patient - at the time of its admission to Neurologic Clinic (initial EDSS), and on December 2006 (final EDSS).

It was analyzed the ethnic groups, the benign form (EDSS of 3.0 or lower than 3.0 in the time interval of disease of 10 or more years) ${ }^{13-15}$ and severe form (EDSS greater than 3.0 of less than 10 years of disease). Individuals with onset of the disease before 16 years old were classified as early onset $\mathrm{MS}^{16}$ and late-onset forms, those patients affected over 50 years old ${ }^{17}$. The rate of lethality considered all patients with MS followed at HUCFF-UFRJ. The clinical form was correlated with the date of first relapse, time of disease's evolution, characteristic of the first relapse (monosymptomatic or polisymptomatic), number of relapses per year, initial EDSS at diagnosis, and EDSS at the end of each

Table 1. Patients characteristics, their distribution for clinical forms, duration time of MS, and distribution for number of relapses comparing these features between sever and benign forms.

\begin{tabular}{|c|c|c|c|c|c|c|c|}
\hline \multirow[t]{2}{*}{ Variables } & \multicolumn{2}{|c|}{ Total number of patients } & \multicolumn{2}{|c|}{ Benign forms } & \multicolumn{2}{|c|}{ Severe forms } & \multirow{2}{*}{$\begin{array}{c}\mathrm{P}^{*} \\
\text { value }\end{array}$} \\
\hline & $N$ & $\%$ & $\mathrm{~N}$ & $\%$ & $\mathrm{~N}$ & $\%$ & \\
\hline \multicolumn{8}{|l|}{ Gender } \\
\hline Male & 37 & 30.0 & 6 & 35.3 & 14 & 32.6 & 0.8 \\
\hline Female & 85 & 70.0 & 11 & 64.7 & 29 & 67.4 & \\
\hline \multicolumn{8}{|l|}{ Age of 19 relapse } \\
\hline Average (SD) & \multicolumn{2}{|c|}{$32.2( \pm 10.3)$} & \multicolumn{2}{|c|}{$30.1( \pm 11.0)$} & \multicolumn{2}{|c|}{$34.5( \pm 10.1)$} & \\
\hline \multicolumn{8}{|l|}{ Race } \\
\hline Caucasian & 82 & 67.0 & 10 & 58.8 & 30 & 69.8 & 0.4 \\
\hline Afro-Brazilian & 40 & 33.0 & 7 & 41.2 & 13 & 30.3 & \\
\hline \multicolumn{8}{|l|}{ Clinical forms } \\
\hline RRMS & 106 & 86.8 & 16 & 94.1 & 27 & 62.8 & 0.01 \\
\hline PPMS & 16 & 13.1 & 1 & 5.9 & 7 & 16.3 & 0.2 \\
\hline SPMS & 21 & $17.2^{*}$ & 0 & 0 & 9 & 20.9 & - \\
\hline PRMS & 0 & 0 & 0 & 0 & 0 & 0 & - \\
\hline \multicolumn{8}{|c|}{ Disease duration in years } \\
\hline$\leq 10$ & 74 & 60.6 & & & & & \\
\hline$\geq 10$ & 48 & 39.3 & & & & & \\
\hline \multicolumn{8}{|c|}{ Total number of relapses } \\
\hline Average (SD) & \multicolumn{2}{|c|}{$5.6( \pm 5.6)$} & \multicolumn{2}{|c|}{$6.3( \pm 5.8)$} & \multicolumn{2}{|c|}{$5.7( \pm 4.0)$} & 0.7 \\
\hline \multicolumn{8}{|l|}{ First EDSS } \\
\hline Average (SD) & \multicolumn{2}{|c|}{$2.8( \pm 1.4)$} & \multicolumn{2}{|c|}{$3.0( \pm 1.8)$} & \multicolumn{2}{|c|}{$3.0( \pm 1.6)$} & - \\
\hline \multicolumn{8}{|l|}{ Lastl EDSS } \\
\hline Average (SD) & \multicolumn{2}{|c|}{$3.8( \pm 2.4)$} & \multicolumn{2}{|c|}{$2.0( \pm 1.0)$} & \multicolumn{2}{|c|}{$4.6( \pm 1.6)$} & - \\
\hline \multicolumn{8}{|c|}{ Functional systems more affected } \\
\hline Polisymptomatic & 98 & $86.7^{* *}$ & 3 & 20.0 & 18 & 42.9 & 0.1 \\
\hline Pyramidal & 48 & 42.4 & & & & & \\
\hline Brain stem & 24 & 12.0 & & & & & \\
\hline Sensitive & 16 & 14.1 & & & & & \\
\hline Cerebellar & 10 & 8.8 & & & & & \\
\hline Visual & 7 & 6.2 & & & & & \\
\hline
\end{tabular}

*Comparison between benign and severe forms; ${ }^{* *}$ Functional systems were performed in 113 patients therefore these values are reference to these patients and no about total number of patients that study; RRMS, remitting-relapsing multiple sclerosis; PPMS, primary progressive multiple sclerosis; SPMS, secondary progressive multiple sclerosis; PRMS, progressive relapse multiple sclerosis; *percentual of patients with SPMS in December 2006. EDSS, expanded disability standard scale; SD, standard deviation. 
Table 2. Caucasian and Afro-Brazilian patients' characteristics.

\begin{tabular}{|c|c|c|c|c|c|}
\hline \multirow[t]{2}{*}{ Variables } & \multicolumn{2}{|c|}{ Caucasians } & \multicolumn{2}{|c|}{ Afro-Brazilians } & \multirow{2}{*}{$\begin{array}{c}\mathrm{P} \\
\text { value }\end{array}$} \\
\hline & $\mathrm{N}$ & $\%$ & $\mathrm{~N}$ & $\%$ & \\
\hline \multicolumn{6}{|l|}{ Gender } \\
\hline Female & 58 & 70.7 & 27 & 67.5 & 0.7 \\
\hline Male & 24 & 29.3 & 13 & 32.5 & \\
\hline \multicolumn{6}{|l|}{ Clinical form } \\
\hline PPMS & 10 & 12.2 & 6 & 15.0 & 0.6 \\
\hline RRMS & 53 & 64.6 & 32 & 80.0 & 0.08 \\
\hline SPMS & 19 & 23.2 & 2 & 5.0 & 0.01 \\
\hline \multicolumn{6}{|l|}{ Age of 19 relapse } \\
\hline Average (SD) & \multicolumn{2}{|c|}{$32.3( \pm 10.6)$} & \multicolumn{2}{|c|}{$32.1( \pm 9.8)$} & 0.4 \\
\hline \multicolumn{6}{|c|}{ Total number of relapses } \\
\hline Average (SD) & \multicolumn{2}{|c|}{$6.0( \pm 6.3)$} & \multicolumn{2}{|c|}{$5.0( \pm 4.0)$} & 0.1 \\
\hline \multicolumn{6}{|c|}{ Duration disease in months } \\
\hline Average (SD) & \multicolumn{2}{|c|}{$131( \pm 100.6)$} & \multicolumn{2}{|c|}{$123.9( \pm 89.5)$} & 0.3 \\
\hline
\end{tabular}

year; it was also considered the time of evolution for achieving the EDSS 3.0 and 6.0, number of deaths and its causes, results of cerebrospinal fluid (CSF) and magnetic resonance imaging of the brain (MRC) and the spinal cord (MRS).

Ethnic classification considered African-Brazilian ${ }^{18}$ those patients with black ancestors until the third generation, and Caucasians, patients who had no ancestral knowledge.

Data were entered into Excel ${ }^{\circledR}$ spreadsheet and file generated was transported to the Epi-Info ${ }^{\circledR}$ version 6.04 for calculation of measures of frequency and statistical analysis. It was made correlation of the variables and t test was used to calculate the $\mathrm{p}$-value when compared to averages in absolute values of the groups studied. Values were considered significant at $p<0.05$. It was considered good association value of $r \geq 0.60$.

The project was approved by the National Council on Ethics in Research (CONEP), with the registration number 1265, to May 29, 2000. All patients or responsible signed a free and informed consent term.

\section{RESULTS}

267 patients were evaluated in the Idiopathic Inflammatory Demyelinating Diseases (IIDD) of CNS clinic of the HUCFF-UFRJ registered and monitored in the Neurology Department. Of those, 188 met criteria for Poser et al. at the beginning of 1983, and for MC Donald et al. from 2001. Sixtysix (66) patients were excluded from analysis of this clinical study because they had failed to appear for reassessment. Characteristics of patients included with regard to gender, ethnicity and age of onset of symptoms can be seen in Table 1.

Among 85 women, 27 (31.7\%) were African-Brazilian and 58 (68.2\%) were Caucasian. Of 37 men, 13 (35.1\%) were African-Brazilians and 24 (64.8\%) were Caucasians. Five (4.0\%) patients had early onset MS and 6 (4.9\%), had late onset MS. We found 17 patients with benign forms (13.9\%) and 43 patients with severe forms (35.2\%).

The comparison between benign and severe forms of MS in our population is shown in Table 1. It was found significant association between benign MS and RRMS $(p=0.01)$. The total time of illness among patients who had benign MS ranged from 120 to 252 months (mean of $166.9 \pm 42.6)$ and severe MS ranged from 12 to 120 months (mean 124.7 $\pm 93,8$ ). The time interval between the first and second relapse in benign forms ranged from 2 to 180 months (mean 68.9 months \pm 52.8 ). In severe forms ranged from 1 to 132 months (mean $39.5 \pm 54.4$ months).

Interval of time to achieve EDSS 3.0 and EDSS 6.0 was four times longer in benign MS. SPMS was more frequent in Caucasians ( $p=0.01)$. It was noticed trend of association between RRMS and Caucasians (Table 2). In severe forms of PPMS, it was found 6 female patients (37.5\%) and 10 male patients (62.5\%). Six patients were African-Brazilian and 10 patients were Caucasian.

The functional systems more affected were: pyramidal in 12 cases (80.0\%), cerebellar in 2 cases (13.3\%) and brainstem in 1 case (6.7\%). The average age of disease's onset in PPMS was $37.6( \pm 9.3)$ with disease's median time of 158.6 $( \pm 105.3)$ months. Average of initial EDSS was $3.2( \pm 1.0)$ and the final EDSS $5.3( \pm 1.7)$.

It took patients with PPMS an average 79.5 months to reach EDSS 3.0 and 112 months to reach EDSS 6.0. It took patients with RRMS an average 80.3 months to reach 3.0 EDSS while the SPMSP took 96 months to reach EDSS 3.0. Regarding interval of time to achieve the EDSS 6.0, patients with RRMS took 109 months and those with SPMS took 111 months. Time average between first and second relapse was 38.4 months ( 1 to 420 months \pm 53.5 ). 
Table 3. Comparison between RRMS forms with other Brazilian stydies and our series.

\begin{tabular}{|c|c|c|c|c|c|c|c|c|}
\hline & $\begin{array}{l}\text { Tilbery } \\
\text { et al. } \\
\mathrm{N}=214\end{array}$ & $\begin{array}{l}\text { Papais- } \\
\text { Alvarenga } \\
\text { et al. } \\
\mathrm{N}=88\end{array}$ & $\begin{array}{c}\text { Brito } \\
\text { Ferreira } \\
\text { et al. } \\
\mathrm{N}=118 .\end{array}$ & $\begin{array}{c}\text { Oliveira } \\
\text { et al. } \\
\mathrm{N}=50\end{array}$ & $\begin{array}{c}\text { Callegaro } \\
\text { et al. } \\
\mathrm{N}=262\end{array}$ & $\begin{array}{c}\text { Moreira } \\
\text { et al. } \\
\mathrm{N}=302\end{array}$ & $\begin{array}{c}\text { Arruda } \\
\text { et al. } \\
\mathrm{N}=200\end{array}$ & $\begin{array}{c}\text { Present } \\
\text { study } \\
N=122\end{array}$ \\
\hline \multicolumn{9}{|l|}{ Gender } \\
\hline Female & $130(p=0.8)$ & $67(p=0.8)$ & $67(p=0.3)$ & $28(p=0.5)$ & $160(p=0.6)$ & $172(p=0.5)$ & ND & 64 \\
\hline Male & 45 & 21 & 16 & 7 & 46 & 48 & & 21 \\
\hline \multicolumn{9}{|c|}{ Age of 19 relapse, (average) } \\
\hline Female & 28 & 28.4 & 33.2 & 27 & ND & 28.6 & 32.0 & 31.2 \\
\hline Male & 30 & 26.4 & & & & & & \\
\hline \multicolumn{9}{|l|}{ Race } \\
\hline Caucasian & $166(p<0.05)$ & $60(p=0.5)$ & ND & ND & ND & ND & $197(p<0.05)$ & 53 \\
\hline Afro-Brazilian & 9 & 28 & & & & & 3 & 32 \\
\hline \multicolumn{9}{|l|}{ Functional systems } \\
\hline Cerebellar & NA & 17 & NA & NA & NA & 0 & 126 & 8 \\
\hline Pyramidal & NA & 46 & NA & NA & NA & $25(p<0.05)$ & 99 & 24 \\
\hline Midbrain & NA & 25 & NA & NA & NA & & & \\
\hline Sensitive & NA & 45 & NA & NA & NA & ND & 126 & 23 \\
\hline Visual & NA & 26 & NA & NA & NA & $65(p=0.05)$ & 108 & 14 \\
\hline Esfincters & NA & 23 & NA & NA & NA & $52(p=0.08)$ & 79 & 11 \\
\hline Last EDSS (average) & NA & & $0.0-6.5$ & 4.2 & NA & 3.2 & NA & 2.48 \\
\hline
\end{tabular}

NA, not avaible; OBS, $p$ values are related to comparisons between Brazilian studies and our series.

Of 106 patients who had RRMS, 21 progressed to SPMS. In this form, 15 patients $(71.4 \%)$ were female and $6(28.6 \%)$ were males. Two were African-Brazilians (9.5\%) and 19 (90.5\%) were Caucasians. The average duration of the disease in these patients was 150.8 months $( \pm 98.5)$ with minimum time of 12 months and a maximum of 360 months. The average age in the first relapse was $32( \pm 8.3)$ years, the functional systems more affected were: pyramidal in 8 patients $(38.0 \%)$, brainstem in 8 patients $(38.0 \%)$, followed by sensory involvement in 3 patients (14.3\%) and cerebellar and visual functional systems on 1 respectively (4.8\%), brainstem and sphincter in 2 (9.5\%). The average of initial EDSS was $2.7( \pm 1.9)$ and the final EDSS was $6.7( \pm 2.0)$.

It was investigated correlation between age of the first relapse and final EDSS, time interval of disease and EDSS final, interval of time and number of relapses, time to reach EDSS 3.0 and 6.0 and final EDSS, and number of relapses and EDSS final. In none of these correlations, not only in the population of MS studied, but also after stratification in benign MS and severe MS, or by stratification in ethnic groups, no positive correlation was found $(p<0.60)$.

We present in Table 3 some studies of Brazilian cases series compared with our series. Analysis was performed only with the characteristics of the RRMS.

In 122 cases, search for oligoclonal bands (OCB) in the CSF was made on 73 of them, and it was present in 47 (64.4\%). In another 49 patients it was calculated the index of intrathecal lgG synthesis and found it in $72.7 \%$ of cases.
There were 4 deaths in the total of patients with MS during these 28 years of monitoring in HUCFF-UFRJ. At the time of death, 2 patients were receiving treatment for MS with disease's course modifier drugs. Other 2 patients received treatment during disease's relapses. MS was the underlying cause of death in 4 cases, and in 3 of them, cause of death was urinary sepsis and in the fourth case, abdominal sepsis secondary to surgery for malignant neoplasm in the stomach (adenocarcinoma). The fatality rate of MS in our series was $2.1 \%$ in 28 years.

\section{DISCUSSION}

The growing number of descriptions of national series is contributing to the understanding of the clinical profile and evolution of MS in Brazil. This study was initiated in August, 2004. Criteria for McDnald et al., 2001, contributed to the inclusion of PPMS forms and for the monitoring of the first relapse in monosymptomatic ways, named Clinical Isolated Syndromes (CIS). Considering the cohort of patients with IIDD of CNS followed in the Neurology Department of HUCFF-UFRJ, we found the frequency of MS 70.4\%, confirming its importance among IIDD of CNS. Our patients with MS confirm the predominance of females in a gender ratio of 2, 3:1. Variations in Brazilian series showed distribution of 1.6:1 to 4.1:1. Our series is similar to the series Tilbery et al. ${ }^{19}$, Lana et al. ${ }^{20}$, Leite et al. ${ }^{21}$, and Oliveira et al..$^{22}$. Among 85 females, 58 (68.2\%) were Caucasian, and 27 (31.7\%) were African-Brazilian. In male serie, 
13 (35.1\%) were African-Brazilians and 24 (64.8\%) were Caucasians. Papais-Alvarenga et al..$^{23}$ in 1995, in her series of 88 cases, found higher proportion of African-descendent women (37.3\%) compared to our population. However, in our male series, frequency of African-Brazilian was higher (35.1\%); both studies were conducted in the municipality of Rio de Janeiro. Generally the MS is not very common in African-descendents, but the frequency of about a third of that ethnic group in the series of patients with MS has been repeated in states of southeast and northeast of Bra$\mathrm{zil}^{24}$. When we compare the frequency of African-Brazilians between our series and the series of Tilbery et al..$^{19}$, in São Paulo city, we found significant differences in patients African-descendents with MS ( $p<0.05)$, as well as Arruda et al. series ${ }^{25}(p<0.05)$. Our results reflect the combination of MS with populations of European origin, which in Brazil have greater gradient of north-south distribution.

These data are consistent with the possible existence of greater susceptibility gene associated with MS discovered by Davenport ${ }^{26}$ and found by other studies in Nordic populations and with heterogeneous distribution of alleles HLA Class II (DRB1* 0602, DQA1*0102, DRB1*1501) found in Caucasians and African-descendants in Rio de Janeiro city ${ }^{27}$.

Our results of the average age of 32.2 years old to the first relapse are similar to those results found by Oliveira et al. ${ }^{22}$ (32.5) and Arruda et al. ${ }^{25}$. (32.0). We found frequency of $4.0 \%$ of early onset multiple sclerosis (EOMS), higher than found in world literature that is $2.7 \%^{15}$. It was not possible to compare with the Brazilian series, because no data were available. We found a frequency of $4.9 \%$ of late onset multiple sclerosis (LOMS), similar to findings of Martinelli ${ }^{17}$. The small number of patients with EOMS and LOMS did not allow a stratified analysis of these two groups. Brazilian studies do not mention the frequency of those MS forms.

Clinical form RRMS predominated over other forms $(86.8 \%)$ in our series analysis with no significant difference ( $p>0.05$ ) with the frequency found in other Brazilian studies such as Tilbery et al. ${ }^{19}$ (82\%), Arruda et al. ${ }^{25}$ (91\%), Callegaro et al. ${ }^{28}$ (78.6\%), and it was lower than observed by Brito-Ferreira et al. ${ }^{29}$ (70.3\%) and Moreira et al. ${ }^{30}$ (72\%). We found PPMS in the frequency of $13.1 \%$, slightly higher than the number of Callegaro et al. ${ }^{28}$ but on values very different from the rest of the studies. We found $17.2 \%$ of patients with SPMS, a little larger than reported in the world literature $^{8}$. If we consider that about $60 \%$ of patients with RRMS evolve to SPMS after 10 years of illness ${ }^{14}$, the long period of monitoring our patients can justify this higher frequency of SPMS.

The duration of the disease ranged from 1 to 42 years and average value was 10.6 years. In our series there were 4 deaths, 3 of them were females. Our study shows fa- tality rate of $2.12 \%$. It was not possible to compare it to other Brazilian series because none of these studies presented this description. Bergamaschi et al. ${ }^{31}$ compared two cohorts of patients with MS evaluated in different times, and found a reduction of mortality caused by MS, from $25.0 \%$ to $6.0 \%$ of the earlier cohort. It was associated as risk factors for an unfavorable course of MS, lower age of onset of disease, disability early in a short interval between the onset of the disease and its progression to SPMS. In Austria, the prospective studies showed reduction in the mortality rate of MS from 1.41 (1970-1979) to 0.98 (1980-1989), and 0.70 (1990-2001) for 32 years of evolution, and MS was reported as underlying cause of death in a minority of patients ${ }^{32}$. Considering these findings, our mortality rate was higher than that observed in those countries. MS as underlying cause of death found in other studies is similar to our findings. Hansen et al. ${ }^{33}$ showed that MS has been shown in $82 \%$ of the certificates of death as a contributory cause of death. On the occasion of the death of our patients with MS, 2 patients were receiving treatment for MS with immunosuppressive and immunomodulatory drugs and the other 2 were treated during relapses of the disease.

Our series showed average of 5.6 relapses (from 1 to $40)$, and the average interval of time between the first and second relapses was 38.4 months (from 1 to 420 months). We found no positive association between the duration of the disease and number of relapses $(p<0.60)$.

The EDSS values varied in average of 2.8 for initial EDSS to 3.8 for final EDSS. We found no correlation between the age of the first relapse and final EDSS $(r=0.00)$, between the time of disease and final EDSS $(p<0.60)$, between the time interval to reach 3.0 EDSS and 6.0 EDSS and final EDSS $(p<0.60)$ or between the number of relapses and final EDSS $(p<0.60)$. Our results are similar to those found by Callegaro et al. ${ }^{28}$, which found no positive association between age and final EDSS in first relapse, however they are divergent of the association found by these authors between interval of illness duration and final EDSS. Patients who presented PPMS took an average 79.5 months to reach EDSS 3.0 and 112 months to reach EDSS 6.0. Patients with RRMS took an average 80.3 months to reach EDSS 3.0, whereas in SPMS, they took 96 months to reach EDSS 3.0. Regarding EDSS 6.0, patients with RRMS took 109 months and patients with SPMS took 111 months. It was not possible to draw a comparison with the Brazilian literature, because there was no similar data available in these studies. We found 17 patients (14\%) with benign MS as Weinshenker et al. criteria ${ }^{12-34}$. Moreira et al. ${ }^{30}$, found a higher percentage of patients with benign form (19.8\%), contrasting it with other Brazilian reports, which had a frequency of $7 \%$ in Arruda et al. serie $e^{25}$, as the same in 
Brito Ferreira et al. report ${ }^{29}$, and $8 \%$ in Oliveira et al. ${ }^{22}$. Our lower percentage (14\%) for benign MS than that found in the literature might be explained based on a long period of monitoring these patients, because literature refers fall to less than $20 \%$ of patients with benign form depending on the duration time of the disease. Considering this, our findings are similar. In our series, the group of patients with benign MS did not differ from the group with severe form (duration of the disease less than 10 years and final EDSS greater than 3.0) in relation to gender, ethnicity, the total number of relapses, functional systems most affected, presence of OCB in the CSF or the death occurrence and clinical form of the disease ( $p>0.05)$. Regarding the frequency of clinical form of evolution, it was found significant association between RRMS and benign MS when compared to severe MS $(p=0.01)$. These findings are similar to those considered by other authors that include the clinical course remitting-relapsing among criteria for lower morbidity.

The time interval of the disease among patients who had a benign MS ranged from 120 to 282 months, and the interval between the first and second relapse in benign forms ranged from 2 to 180 months. Interval of time to reach EDSS 3.0 in benign forms was of 182 months and in severe forms of 38.6 months, four times faster than found in benign MS. Same values and proportion were observed in interval of time to achieve EDSS 6.0 in both clinical forms studied. None of Brazilian studies calculated interval of time to achieve EDSS 3.0 and 6.0. In benign MS we did not find positive association between age of the first relapse and final EDSS $(p<0.60)$, duration of disease and final EDSS $(p<0.60)$, duration of disease and number of relapses $(r<0.60)$ and number of relapses and final EDSS ( $p<0.60)$. None of Brazilian series studied this correlation. Severe MS was found in 43 patients (35.2\%). We found no positive association between age of the first relapse and final EDSS $(p<0.60)$, duration of disease and final EDSS $(p<0.60)$, duration of disease and number of relapses $(p<0.60)$, and number of relapses and final EDSS $(p<0.60)$. None of Brazilian series studied made this correlation. The frequency about one third of patients African-descendants in series of some Brazilian States of the southeast, especially in Rio de Janeiro city, as shown by Papais-Alvarenga et al. ${ }^{23}$, the influence of ethnicity observed in functional systems, and genetic differences shown by Alves-Leon et al. ${ }^{27}$, motivated analysis of our series into two groups: Caucasians and African-Brazilians. We found no difference in frequency of gender between two groups ( $p>0.05)$, or the presence of OCB in the CSF ( $>>0.05)$. We found a significant association between SPMS and Caucasians ( $p=0.01$ ), and monosymptomatic involvement in the first relapse was more frequent than polisymptomatic $(p=0.04)$. We found no association between ethnicity and functional systems, but our current series aimed to analyze the first relapse, and not the total commitment of all relapses as did by another serie of Rio de Janeiro city.

We found 82 patients Caucasians. We found no positive association between age of the first relapse in final EDSS ( $r=0.04)$, time interval of disease and final EDSS I $(r=0.43)$, interval of time and number of disease relapses $(r=0,29)$, interval of time to EDSS 3.0 and $6.0(r=0.11)$ and number of relapses and final EDSS $(r=0.15)$. None series Brazilian studied did this correlation.

We found 40 patients African-Brazilians. We found no positive association between age of the first relapse and final EDSS ( $r=0.10$ ), time interval of disease and final EDSS $(r=0.45)$, interval of time and number of relapses $(r=0,15)$, interval of time to EDSS 3.0 and $6.0(r=0.20)$ and number of relapses and final EDSS ( $r=0.14)$. None Brazilian series studied this correlation. It was selected as severe MS with regard to ethnicity. We found 30 Caucasians patients with EDSS greater than 3.0 with the duration of the disease less than 120 months and 13 African-Brazilian with the same criterion. The comparison of these two groups of patients showed RRMS was more frequent in Caucasians with the most severe forms of MS ( $p=0.05)$. No other significant association was observed. No Brazilian series studied this correlation.

In conclusion, MS is more prevalent in females, a ratio of genera of 2.3: 1, and in Caucasians than African-descendants, starting mainly in young adults, between 30 and 40 years old. Clinical form - RRMS - predominated over the other forms (86.8\%), followed by PPMS (13.1\%). Forms of SPMS were found in a higher proportion (17.2\%) than in other Brazilian series. Early onset MS and late onset MS are frequent conditions. Benign MS corresponds to $14 \%$ of patients and severe MS forms to $35.2 \%$. We found a significant association between RRMS and benign forms compared to severe forms $(p<0.05)$. The interval of time to achieve EDSS 3.0 and 6.0 in benign forms was four times greater than that found in severe forms. In SPMS, the involvement monosymptomatic of the first relapse was more frequent than the polisymptomatic $(p<0.05)$. The fatality rate of MS was $2.1 \%$. We found no positive association between age of relapse and final EDSS, duration of disease and final EDSS, time of disease and the number of relapses, time to achieve EDSS 3.0 and 6.0 and final EDSS, number of relapses in final EDSS $(p<0.60)$ when compared all patients with MS, or the benign and severe forms, or the two ethnic groups. Our number of patients with MS African-descendants is significantly higher than those found in the cities of São Paulo and Curitiba $(p<0.05)$. 


\section{REFERENCES}

1. Arnason B. The role of cytokines in multiple sclerosis. Neurology 1995; 45(Suppl):S554-S555.

2. Brosnan CF, Canella B, Battistini L, Raine CS. Cytokine localization in multiple sclerosis lesions: correlation with adhesion molecule expression and reactive nitrogen species. Neurology 1995;45(Suppl):S16-S21.

3. Ristori G, Montesperelli C, Pena A et al. Global immune disregulation in multiple sclerosis: from the adaptative response to the innate immunity. J Neuroimmunol 2000;107:216-219.

4. Carvalho A, Sant' Anna G, Liem A et al. Fine specificity of antibody responses to myelin sequences in association with HLA class II alleles in the serum of brazilian patients with multiple sclerosis. Mul Scler 2002;7:407-408

5. Correlale J, Tenembaum SN. Myelin basic protein and myelin oligodendrocyte glycoprotein T- cell repertoire in childhood and juvenile multiple sclerosis. Mult Scler 2006;12:412-420.

6. Merkler D, Schmelting B, Czeh B, Fuchs E, Stadelmann C, Bruck W. Myelin oligodendrocyte glycoprotein-induced experimental encephalomyelitis in the common marmoset reflects the immunopathology of pattern II multiple sclerosis lesions. Mult Scler 2006;12:369-374.

7. Imitola J, Chitnis T, Khoury SJ. Insights into the molecular pathogenesis in the pathogenesis of progression in multiple sclerosis: potential implications for future therapies. Arch Neurol 2006;63:25-32.

8. Lublin FD, Reingold SC. Defining the clinical course of multiple sclerosis: results of an international survey. National Multiple Sclerosis Society (USA) Advisory Committee on Clinical Trials of New Agents in Multiple Sclerosis. Neurology 1996;46:907-911.

9. Rudick R, Antel J, Confavreux C et al. Clinical outcomes assessment in multiple sclerosis. Ann Neurol 1996;40:469-479.

10. Poser CM, Paty DW, Scheinberg L et al. New diagnostic criteria for multiple sclerosis: guidelines for research protocols. Ann Neurol 1983;13: 227-231.

11. McDonald WI, Compston A, Edan G et al. Recommended diagnostic criteria for multiple sclerosis: guidelines from the international panel on the diagnosis of multiple sclerosis. Ann Neurol 2001;50:121-127.

12. Kurtzke JF. Rating neurological impairment in multiple sclerosis: an expanded disability status scale (EDSS). Neurology 1983;33:1444-1452.

13. Weinshenker BG, Santrach P, Bissonet AS, et al. Major histocompatibility complex class II alleles and the course and outcome of MS: a population-based study. Neurology 1998;51:742-747.

14. Hawkins SA, Mc Donnell GV. Benign multiple sclerosis? Clinical course, long term follow up, and assessment of prognostic factors. J Neurol Neurosurg Psychiatry 1999;67:148-152.

15. on of a benign course of multiple sclerosis on clinical grounds: a systematic review. Mult Scler 2001;7:345-347.

16. Ghezzi A. Clinical characteristics of multiple sclerosis with early onset. Neurol Sci 2004;25(Suppl):S336-S339.

17. Martinelli V, Rodegher M, Morola L, Comi G. Late onset multiple sclerosis: clinical characteristics, prognostic factors and differential diagnosis. Neurol Sci 2004;25(Suppl):S350-S355.
18. Ribeiro D. O povo brasileiro: a formação e o sentido do Brasil. São Paulo: Companhia das Letras, 1995/1996.

19. Tilbery CP, Felipe E, Baldauf CM, Peres MF. Multiple sclerosis: clinical analysis and development of 214 cases. Arq Neuropsiquatr 1995;2: 203-207.

20. Lana-Peixoto MA, Frota E, Campo GB, Botelho CM, Aragão AL. The prevalence of multiple sclerosis in Belo Horizonte. Mult Scler 2002; 8(Suppl):S38.

21. Leite ACCB, Andrade C, Novis S. Esclerose múltipla no Rio de Janeiro: apresentação clínica em 51 casos. Arq Neuropsiquiatr 1990;48(Suppl):S66.

22. Oliveira EML, Annes M, Oliveira ASB, Gabbai AA. Estudo clínico de 50 pacientes acompanhados no ambulatório de neurologia UNIFESPEPM. Arq Neuropsiquiatr 1999;57:51-55.

23. Papais-Alvarenga RM, Santos CMM, Colin DD, et al. Esclerose múltipla: influência do sexo e etnia no perfil clínico de 88 pacientes no município do Rio de Janeiro. Rev Bras Neurol 1995;31:89-98.

24. Alves-Leon SV. HLA DQB1*0602 confere susceptibilidade genética para Esclerose Múltipla numa população de pacientes afro-brasileiros da cidade do Rio de Janeiro. Tese. Rio de Janeiro, 1999.

25. Arruda WO, Scola RH, Teive HA, Werneck LC. Multiple sclerosis: report on 200 cases from Curitiba, Southern Brazil and comparison with other Brazilian series. Arq Neuropsiquiatr 2001;59:165-170.

26. Davenport CB. Multiple sclerosis from de stand point of geographic distribution and race. Arch Neurol 1992;8:51-58.

27. Alves-Leon SV, Alvarenga RP, Magalhães M, Alvarenga M, Thuler LC, Fernandez OF. Ethnicity-dependent association of HLA DRB1-DAQ1DAB1 alleles in Brazilian multiple sclerosis patients. Acta Neurol Scand 2007;115:306-311.

28. Callegaro D, Goldbaum M, Morais L et al. The prevalence of multiple sclerosis in the city of São Paulo, Brazil, 1997. Acta Neurol Scand 2001, 104:208-213.

29. Brito Ferreira ML, Machado MIM, Vilela ML, et al. Epidemiologia de 118 casos de esclerose múltipla com seguimento de 15 anos no centro de referência do Hospital da Restauração de Pernambuco. Arq Neuropsiquiatr 2004;62:1027-1032.

30. Moreira MA, Felipe E, Mendes MF, Tilbery CP. Esclerose múltipla: estudo descritivo de suas formas clínicas em 302 casos. Arq Neuropsiquiatr 2000;58:460-466

31. Bergamaschi R, Montomoli C, Candeloro E, Fratti C, Citterio A, Cosi V. Disability and mortality in a cohort of multiple sclerosis patients: a reappraisal. Neuroepidemiology 2005;25:15-18.

32. Ekestern E, Lebhart G. Mortality from multiple sclerosis in Austria 19702001: dynamics, trends and prospects. Eur J Neurol 2004;11:511-520.

33. Hansen HB, Henriksen NK, Stenager E. Trends in survival and cause of death in Danish patients with multiple sclerosis. Brain 2004;127: 844-850.

34. Glad S, Nyland H, Myr K-M. Benign multiple sclerosis. Acta Neurol Scand 2006;113(Suppl):S55-S57. 